\title{
Influence of Two-Stage Combinations of Constructed Wetlands on the Removal of Antibiotics, Antibiotic Resistance Genes and Nutrients from Goose Wastewater
}

\author{
Xiaofeng Huang ${ }^{1}$, Yi Luo ${ }^{1}$, Zuolan Liu ${ }^{1}$, Changlian Zhang ${ }^{1}$, Hang Zhong ${ }^{1}{ }^{\mathbb{D}}$, Jiajia Xue ${ }^{1}$, \\ Qigui Wang ${ }^{1,2}$, Zhiping $\mathrm{Zhu}^{3, *}$ and Chao Wang ${ }^{1,2, *}$ \\ 1 Poultry Science Institute, Chongqing Academy of Animal Sciences, Chongqing 402460, China; \\ hxf2007@yeah.net (X.H.); homleestar@163.com (Y.L.); liuzuolan9229@163.com (Z.L.); zcl0326@163.com (C.Z.); \\ hangzhongcqaas@163.com (H.Z.); xuejiajia25@163.com (J.X.); wangqigui@hotmail.com (Q.W.) \\ 2 Scientific Observation and Experiment Station of Livestock Equipment Engineering in Southwest, Ministry \\ of Agriculture, Chongqing 402460, China \\ 3 Institute of Environment and Sustainable Development in Agriculture, Chinese Academy of Agricultural \\ Sciences, Beijing 100081, China \\ * Correspondence: zhuzhiping@caas.cn (Z.Z.); wangccq@foxmail.com (C.W.); Tel.: +8613801130791 (Z.Z.); \\ +8613618208706 (C.W.)
}

Received: 11 September 2019; Accepted: 16 October 2019; Published: 21 October 2019

\begin{abstract}
Antibiotic and antibiotic resistance genes (ARGs) have been considered as emerging environmental contaminants and possess potential crisis to global public health. However, little is known about the differences between various configurations of two-stage combinations of constructed wetlands (CWs) on antibiotics and ARG removal from wastewater. In the study, three configurations of two-stage hybrid CWs (horizontal subsurface flow-down-flow vertical subsurface flow CWs, HF-DVF; horizontal subsurface flow-up-flow vertical subsurface flow CWs, HF-UVF; down-flow vertical subsurface flow-up-flow vertical subsurface flow CWs, DVF-UVF) were operated to evaluate their ability to remove high-concentration antibiotics (tilmicosin-TMS and doxycycline-DOC), ARGs (seven tet genes and three erm genes), intI1, 16S rRNA, and nutrients from goose wastewater. The results showed that all three hybrid CWs could remove more than $98 \%$ of TMS and DOC from wastewater, without significant difference among treatments $(p>0.05)$. For ARGs, DVF-UVF showed significantly higher removal efficiencies of intI1,erm $\mathrm{B}, \operatorname{erm} \mathrm{C}, \operatorname{erm} \mathrm{F}, \operatorname{tet} \mathrm{W}$, and tet $\mathrm{G}$ compared to HF-UVF $(p<0.05)$, mainly because they might remove and arrest growth of bacteria. The relatively high removal efficiencies of $\mathrm{NH}_{4}{ }^{+}-\mathrm{N}, \mathrm{NO}_{3}-\mathrm{N}$, and $\mathrm{NO}_{2}{ }^{-}-\mathrm{N}$ were also observed from DVF-UVF, ranging from $87 \%$ to $95 \%$ ( $p>0.05$ ), indicating that anaerobic ammonium oxidation (anammox) might be established in the CWs. Our results demonstrate that the removal performances of antibiotics using two-stage hybrid CWs are not affected by the combined configuration, whereas the combination of DVF and UVF CWs perform better on the removal of ARGs and nutrients compared with HF-DVF and HF-UVF CWs.
\end{abstract}

Keywords: hybrid CWs; combination; antibiotics; antibiotic resistance genes; removal

\section{Introduction}

Antibiotics have been widely used in animal for prophylaxis, therapy, and growth promotion [1,2]. However, due to the over consumption and poor absorption, the majority of antibiotics have been continuously released into the environment and maintain permanent presence [3,4]. As a consequence, 
the antibiotic resistant bacteria and antibiotic resistant genes (ARGs) emerge and spread more rapidly in the environment, and threaten the ecological balance [5,6]. Therefore, the antibiotic and ARGs have been considered as emerging environmental contaminants and potential crises to global public health [7]. In recent years, veterinary antibiotics have been detected in the soil, vegetables, river, and sea, and the highest antibiotic concentration reached $47.0 \mathrm{mg} / \mathrm{L}$ in the Yangtze river of China [8-10]. Correspondingly, high frequency and abundance of ARGs have also been observed in the environment [11,12].

Constructed wetlands (CWs) have been proven as an effective system for removing of antibiotics and ARGs in wastewater, with low maintenance costs and environment-friendly features [13-15]. However, the composition of wastewater became complex in recent years and pollutants could not be treated well by single CW. Then, hybrid CWs that combine different types of CWs were introduced to obtain high removal efficiencies of pollutants $[16,17]$. Results have confirmed that hybrid CWs performed better in nitrogen removal than single $\mathrm{CW}$, because of the combination of nitrification and denitrification provided by various types of CWs $[16,18]$. Moreover, hybrid CWs have also been proved to enhance the removal efficiencies of antibiotics and ARGs compared to single CW [13,19]. Due to the various characteristics of single $\mathrm{CW}$, the different configurations of hybrid CWs could possess distinct microsystems and functions [20]. However, few researches were focused on exploring the differences among various configurations of hybrid CWs on the removal performances of antibiotics and ARGs from wastewater. Recently, horizontal subsurface flow (HF), down-flow vertical subsurface flow (DVF) and up-flow vertical subsurface flow (UVF) CWs were proved to be efficient on wastewater antibiotics and ARG removal, and they have their own advantages regarding pollutant removal [3,21]. Accordingly, we want to combine the three types of CWs (HF, UVF, and DVF) to compose different hybrid CWs (HF-UVF, HF-DVF, and UVF-DVF) and compare their performances on antibiotics and ARG removal from wastewater.

In China, the combination of tilmicosin (TMS) and doxycycline (DOC) has been widely used to cure the respiratory diseases, which is high prevalence and infectious in poultry [22]. As a result, TMS and DOC were detected in the wastewater and researches showed that CWs could efficiently remove the TMS and DOC at a low concentration from wastewater $(36 \mathrm{ng} / \mathrm{L}$ for TMS and $180 \mathrm{ng} / \mathrm{L}$ for DOC) $[23,24]$. However, the dosage of TMS and DOC for cure in geese are increasing as time went on due to the drug resistance of bacteria. Besides, in China, the annual inventory amount of geese was more than 580 million and the daily volume of wastewater was huge owing to the habit of playing with water [25]. Therefore, it is necessary to investigate the removal efficiencies of high-concentration TMS and $\mathrm{DOC}$ by $\mathrm{CWs}$ from goose wastewater. Moreover, seven tet genes $(\operatorname{tet} \mathrm{O}, \operatorname{tet} \mathrm{Q}, \operatorname{tet} \mathrm{W}, \operatorname{tet} \mathrm{A}, \operatorname{tet} \mathrm{C}$, tet $\mathrm{G}$, and tet $\mathrm{X})$ and three erm genes (erm $\mathrm{B}$, erm $\mathrm{F}$, and $\mathrm{erm} \mathrm{C})$ were chosen as representatives of tetracycline (including TMS)—resistance and macrolide (including DOC)—resistance mechanisms due to their frequent occurrence in wastewater $[26,27]$.

Hence, the main objectives of this study were: (1) to compare the removal efficiencies of high-concentration TMS and DOC and ARGs in three configurations of two-stage hybrid CWs (HF-UVF, HF-DVF, and UVF-DVF) form goose waster; and (2) to investigate the removal efficiencies of nutrients in goose wastewater by three configurations of two-stage hybrid CWs.

\section{Materials and Methods}

\subsection{Design of Hybrid CWs}

The experiment was conducted in six CWs including two HF-CWs, two UVF-CWs and two DVF-CWs. All the CWs were set up in stainless steel containers. HF-CWs $(0.9 \mathrm{~m}$ height $\times 0.43 \mathrm{~m}$ width $\times 0.7 \mathrm{~m}$ length) were composed of $20 \mathrm{~cm}$ bottom layer of gravel, $40 \mathrm{~cm}$ middle layer of ceramsite and zeolite (v:v $=1: 1)$ and $20 \mathrm{~cm}$ top layer of red soil. vertical subsurface flow constructed wetlands (VF-CWs) (diameter $0.62 \mathrm{~m}$, height $0.9 \mathrm{~m}$ ) were filled with three layers (from lower to upper): 20 $\mathrm{cm}$ layer of gravel, $40 \mathrm{~cm}$ layer of ceramsite and zeolite ( $\mathrm{v}: \mathrm{v}=1: 1)$, and $20 \mathrm{~cm}$ layer of red soil. All 
CWs were planted with Phragmites australis on the top layers. Then, every two types of the CWs were connected into three configurations of two-stage hybrid CWs (HF-UVF, HF-DVF, and DVF-UVF).

The experiment was performed in the poultry scientific research base of Chongqing Academy of Animal Science, Chongqing City, China. Goose wastewater was obtained from sedimentation tank of the research base, having an average $25.55 \mathrm{mg} / \mathrm{L}$ total nitrogen (TN), $5.53 \mathrm{mg} / \mathrm{L}$ nitrate nitrogen $\left(\mathrm{NO}_{3}{ }^{-}-\mathrm{N}\right), 1.59 \mathrm{mg} / \mathrm{L}$ nitrite nitrogen $\left(\mathrm{NO}_{2}{ }^{-}-\mathrm{N}\right), 4.74 \mathrm{mg} / \mathrm{L}$ ammonia nitrogen $\left(\mathrm{NH}_{4}{ }^{+}-\mathrm{N}\right), 13.39 \mathrm{mg} / \mathrm{L}$ total phosphorus (TP), $25.65 \mathrm{mg} / \mathrm{L}$ chemical oxygen demand (COD), 10,461.54 ng/L TMS, and $125.54 \mathrm{ng} / \mathrm{L}$ DOC. According to the ratio of antibiotics in real wastewater and the dosage for cure in practice, the physicochemical properties of TMS and DOC were spiked into the wastewater to produce individual high concentrations of about 2,500,000 and 30,000 ng/L. The synthetic wastewater was prepared at day 0 and day 42 and stocked in a cistern, and then continuously infused into each hybrid CW by peristaltic pump at a flow rate of $6.25 \mathrm{~mL} / \mathrm{min}$. The corresponding theoretical hydraulic residence time (HRT) was 6 days in each hybrid CWs ( 3 days by each single CW). This experiment was initiated in August 2018 and lasted for 84 days. In this period, samplings were carried out on day 21, 42, 63, and 84 at 8:00, 12:00, and 16:00, collecting the influent and effluent in each hybrid CWs.

\subsection{Analysis of TMS and DOC}

The antibiotics in wastewater were analyzed following the methods described by Huang et al. [28]. Water samples were filtered through $0.45 \mu \mathrm{m}$ mixed cellulose ester filters and adjusted to $\mathrm{pH} 4.0$ by $\mathrm{HCL}$, after which $0.2 \mathrm{~g} / \mathrm{L} \mathrm{Na}_{2}$ EDTA was added. Then, samples were extracted using $200 \mathrm{mg} / 6 \mathrm{~mL}$ Oasis HLB extraction cartridges, and then washed by deionized water and dried under a gentle stream air. The dried samples were eluted by pure methanol, dried under a gentle stream of nitrogen gas at $40{ }^{\circ} \mathrm{C}$ and re-dissolved in $1 \mathrm{~mL}$ of $20 \%$ methanol for subsequent LC-MS/MS analysis. A reverse phase C-18 column (Kinetex, $2.6 \mu \mathrm{m}, 100 \times 4.6 \mathrm{~mm}$, Phenomenex, USA) was used to separate the target antibiotics (TMS and DOC). A binary gradient consisted of $0.5 \%$ formic acid water solution for mobile phase A and pure methanol for mobile phase B. Electrospray Ionization (ESI) positive complete scan mode was used for detecting the antibiotics. The quantification of antibiotics was determined using external standard calibration curves and the correlation coefficients were more than 0.99 .

\subsection{Analysis of $16 S$ rRNA, IntI1, and ARGs}

The DNA in wastewater were extracted following the methods described by Sui et al. [29]. Water samples were passed through $0.22 \mu \mathrm{m}$ filter membrane, and then extracted total DNA using FastDNA SPIN Kit for Soil (MP Biochemicals, Solon, OH, USA) according to the manufacturer's instructions. NanoDrop ND-1000 spectrophotometer (NanoDrop Technologies, Willmington, DE, USA) and 2\% agarose gel electrophoresis were used to determine the concentration and qualify of DNA products. Seven tet genes $($ tet $\mathrm{O}$, tet $\mathrm{Q}$, tet $\mathrm{W}$, tet $\mathrm{A}$, tet $\mathrm{C}$, tet $\mathrm{G}$, and tet $\mathrm{X})$, three $\operatorname{erm}$ genes (erm $\mathrm{B}$, $\operatorname{erm} \mathrm{F}$, and $\operatorname{erm} \mathrm{C})$, integrase gene of Class 1 integrons (int11) and 16S rRNA gene were quantified using SYBR Green qPCR mix (Takara, Ostu, Japan) and ABI 7500 Real-time PCR system (Applied Biosystems, Foster City, CA, USA). Primer sequences and annealing temperatures targeting these genes are provided in Table S1. The real-time PCR program was as follows: $30 \mathrm{~s}$ at $95^{\circ} \mathrm{C}$, followed by 40 cycles of $5 \mathrm{~s}$ at $95^{\circ} \mathrm{C}, 34 \mathrm{~s}$ at the annealing temperatures, and $15 \mathrm{~s}$ at $95^{\circ} \mathrm{C}$. Plasmids carrying these selected genes were used to make calibration curves and the correlation coefficients were higher than 0.99. Melting curve analysis and gel electrophoresis were used to confirm product specificity. All PCR reactions were carried out in triplicate.

\subsection{Analysis of Nutrients}

Water nutrients including $\mathrm{TN}, \mathrm{NO}_{3}{ }^{-}-\mathrm{N}, \mathrm{NO}_{2}{ }^{-}-\mathrm{N}, \mathrm{NH}_{4}{ }^{+}-\mathrm{N}, \mathrm{COD}$, and $\mathrm{TP}$ were determined according to the standard methods for the examination of water and wastewater [30]. 


\subsection{Calculation of Removal Efficiencies and Statistical Analysis}

The mass removal efficiency (\%) of antibiotics, ARGs, and nutrients were calculated according to the formula

$$
\text { Removal efficiency }(\%)=((\mathrm{Mi}-\mathrm{Me}) / \mathrm{Mi}) \times 100,
$$

where Mi and Me represent the concentration of antibiotics, ARGs, and nutrients in the influent and effluent respectively.

All experimental values were expressed as means of three measurements with standard deviation. Analysis of variance (ANOVA) in Software SPSS 22.0 (SPSS Inc., Chicago, IL, USA) was used for all statistical analyses, including Bartlett's test for homogeneity of variances analysis and Duncan's test for differences between means. All statements of differences were based on a significance level of $p<0.05$.

\section{Results}

\subsection{Removal Efficiencies of TMS and DOC in Hybrid CWs}

The TMS and DOC concentrations in the influent and effluent of three hybrid CWs have been shown in Figure 1. In the influents, TMS was the predominant compound with the average concentration of $1,495,658.33 \mathrm{ng} / \mathrm{L}$, while DOC was present at relatively low level, with the average concentration at $17,019.17 \mathrm{ng} / \mathrm{L}$. The average effluent antibiotic concentrations for three hybrid CWs (HF-DVF, HF-UVF, and DVF-UVF) were 5360.88, 560.42, and $1497.32 \mathrm{ng} / \mathrm{L}$ for TMS; and 230.53, 193.08, and $298.7 \mathrm{ng} / \mathrm{L}$ for DOC, respectively. The removal efficiencies of TMS, DOC, and total antibiotics (the sum of TMS and DOC - $\sum$ antibiotics) were more than $98 \%$ for all three hybrid CWs and relatively stable along with time, and TMS removal efficiencies in three hybrid CWs were slightly better than DOC (Table 1). However, there were no significant differences among three hybrid CWs for TMS, DOC, and total antibiotics removal $(p>0.05)$, while HF-DVF presented slightly high removal efficiency for DOC.

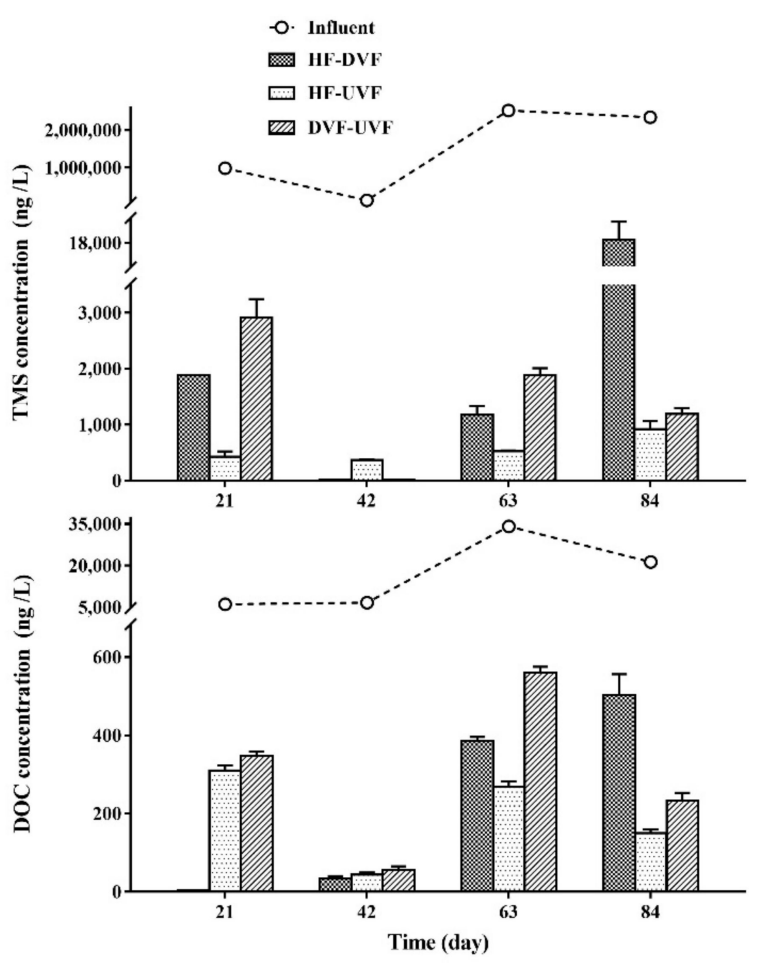

Figure 1. TMS and DOC concentrations in the influent and effluent of different hybrid constructed wetlands. HF-DVF: horizontal subsurface flow-down-flow vertical subsurface flow CWs; HF-UVF: horizontal subsurface flow-up-flow vertical subsurface flow CWs; DVF-UVF: down-flow vertical subsurface flow-up-flow vertical subsurface flow CWs. 
Table 1. Average removal efficiencies of the studied antibiotics, antibiotic resistance genes, and nutrients obtained in each hybrid constructed wetland ${ }^{1}$

\begin{tabular}{|c|c|c|c|}
\hline Items $^{2}$ & HF-DVF (\%) & HF-UVF (\%) & DVF-UVF (\%) \\
\hline \multicolumn{4}{|l|}{ Antibiotics } \\
\hline TMS & $100 \pm 0$ & $100 \pm 0$ & $100 \pm 0$ \\
\hline DOC & $99 \pm 1$ & $98 \pm 2$ & $98 \pm 2$ \\
\hline Eantibiotics & $100 \pm 0$ & $100 \pm 0$ & $100 \pm 0$ \\
\hline \multicolumn{4}{|l|}{ Genes } \\
\hline $16 \mathrm{~S}$ rRNA & $-36 \pm 38^{b}$ & $8 \pm 34^{a b}$ & $45 \pm 22^{a}$ \\
\hline intI1 & $44 \pm 33^{b}$ & $91 \pm 7^{a}$ & $94 \pm 6^{a}$ \\
\hline erm B & $30 \pm 39^{b}$ & $96 \pm 4^{\mathrm{a}}$ & $98 \pm 2^{a}$ \\
\hline erm $\mathrm{F}$ & $58 \pm 29$ & $42 \pm 49$ & $85 \pm 19$ \\
\hline erm C & $64 \pm 30^{b}$ & $92 \pm 5^{\mathrm{a}}$ & $93 \pm 4^{\mathrm{a}}$ \\
\hline Eerm & $49 \pm 13^{b}$ & $64 \pm 25^{a b}$ & $88 \pm 14^{a}$ \\
\hline tet $\mathrm{O}$ & $93 \pm 4$ & $83 \pm 13$ & $76 \pm 19$ \\
\hline tetQ & $50 \pm 52$ & $83 \pm 20$ & $93 \pm 5$ \\
\hline tet $\mathrm{W}$ & $68 \pm 18^{b}$ & $89 \pm 7^{a}$ & $91 \pm 8^{a}$ \\
\hline tet $\mathrm{A}$ & $94 \pm 8$ & $96 \pm 2$ & $67 \pm 51$ \\
\hline tetC & $73 \pm 32$ & $78 \pm 14$ & $91 \pm 7$ \\
\hline tet $\mathrm{G}$ & $57 \pm 29^{b}$ & $79 \pm 15^{a b}$ & $91 \pm 12^{a}$ \\
\hline tet $\mathrm{X}$ & $66 \pm 33$ & $10 \pm 168$ & $85 \pm 13$ \\
\hline$\sum$ tet & $65 \pm 29$ & $64 \pm 42$ & $90 \pm 4$ \\
\hline \multicolumn{4}{|l|}{ Nutrients } \\
\hline $\mathrm{TN}$ & $54 \pm 28$ & $76 \pm 19$ & $68 \pm 25$ \\
\hline $\mathrm{NH}_{4}{ }^{+}-\mathrm{N}$ & $68 \pm 46$ & $73 \pm 44$ & $95 \pm 5$ \\
\hline $\mathrm{NO}_{3}^{-}-\mathrm{N}$ & $59 \pm 40$ & $75 \pm 24$ & $86 \pm 20$ \\
\hline $\mathrm{NO}_{2}^{-}-\mathrm{N}$ & $47 \pm 37$ & $69 \pm 31$ & $90 \pm 10$ \\
\hline $\mathrm{TP}$ & $83 \pm 26$ & $72 \pm 23$ & $82 \pm 19$ \\
\hline COD & $74 \pm 11$ & $59 \pm 25$ & $61 \pm 13$ \\
\hline
\end{tabular}

${ }^{1}$ Data are shown as mean \pm SD and each mean represents 12 samples (3 samples at each time point). ${ }^{2}$ HF-DVF, horizontal subsurface flow-down-flow vertical subsurface flow CWs; HF-UVF, horizontal subsurface flow-up-flow vertical subsurface flow CWs; DVF-UVF, down-flow vertical subsurface flow-up-flow vertical subsurface flow CWs; TMS, tilmicosin; DOC, doxycycline; $\sum$ antibiotics, the sum of TMS and DOC; $\sum$ erm, total erm genes; $\sum$ tet, total tet genes; $\mathrm{TN}$, total nitrogen; $\mathrm{NH}_{4}{ }^{+}-\mathrm{N}$, ammonia nitrogen; $\mathrm{NO}_{3}{ }^{-} \mathrm{N}$, nitrate nitrogen; $\mathrm{NO}_{2}{ }^{-} \mathrm{N}$, nitrite nitrogen; $\mathrm{TP}$, total phosphorus; COD, chemical oxygen demand. ${ }^{a}$ b Different letters in the same row indicate significant differences among three treatments $(p<0.05)$.

\subsection{Removal Efficiencies of $16 S$ rRNA, IntI1, and ARGs in Hybrid CWs}

The $16 \mathrm{~S}$ rRNA, seven tet genes $(\operatorname{tet} \mathrm{O}, \operatorname{tet} \mathrm{Q}, \operatorname{tet} \mathrm{W}$, tet $\mathrm{A}, \operatorname{tet} \mathrm{C}$, tet $\mathrm{G}$, and tet $\mathrm{X})$, three $\operatorname{erm}$ genes $(\operatorname{erm} \mathrm{B}$, $e r m \mathrm{~F}$, and erm $\mathrm{C}$ ) and intI1 were detected in influents and effluents of three hybrid CWs (Figure 2). Among the selected genes, intI1 was found to be the most abundant gene in influents $\left(2.65 \times 10^{7}\right.$ copies $/ \mathrm{mL})$, followed by tet $\mathrm{X}$ and tet $\mathrm{G}\left(2.12 \times 10^{7}\right.$ and $1.99 \times 10^{7}$ copies $\left./ \mathrm{mL}\right)$, while tet $\mathrm{O}$ displayed the lowest abundance $\left(6.17 \times 10^{4}\right.$ copies $\left./ \mathrm{mL}\right)$. The absolute abundances of influent $16 \mathrm{~S}$ rRNA and intI1 decreased along with time, while total tet and erm genes abundances presented high variability throughout the study. 

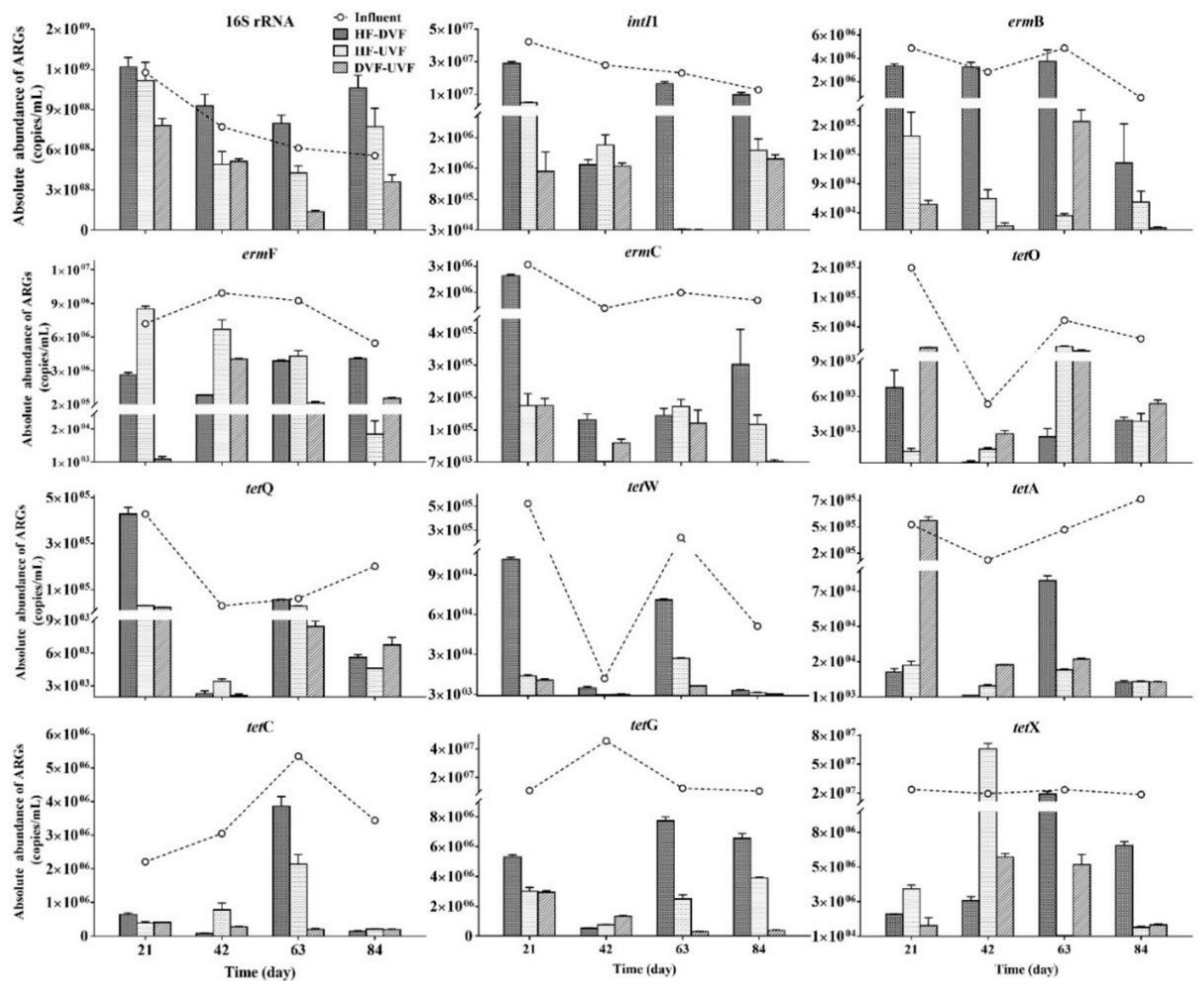

Figure 2. 16S rRNA, intI1, and antibiotic resistant genes abundances in the influent and effluent of different hybrid constructed wetlands.

During CWs treatment process, the removal efficiencies of $16 \mathrm{~S}$ rRNA and total erm genes $\left(\sum\right.$ tet $)$ in DVF-UVF were significantly higher than those in HF-UVF $(p<0.05)$ (Table 1$)$. The abundances of intI1, erm $\mathrm{B}$, and erm $\mathrm{C}$ in HF-DVF and DVF-UVF were reduced by more than $90 \%$, which were significantly higher than those in HF-UVF $(p<0.05)$. There was no significant difference for the removal efficiency of erm $\mathrm{F}$ among three hybrid CWs $(p>0.05)$.

For seven tet genes in three hybrid CWs, except for tetX in HF-UVF, the average removal efficiencies were more than $50 \%$ (Table 1). Compared to HF-UVF, DVF-UVF showed significantly higher removal efficiencies of tet $\mathrm{W}$ and tet $\mathrm{G}(p<0.05)$. There were no significant differences for removal efficiencies of five tet genes $(t e t \mathrm{O}$, tet $\mathrm{Q}$, tet $\mathrm{A}$, tet $\mathrm{C}$, and tet $\mathrm{X})$ and total tet genes $\left(\sum\right.$ tet $)$ among three hybrid $\mathrm{CWs}(p>$ 0.05). However, DVF-UVF presented better performances in $\sum$ tet, tet $\mathrm{Q}$, tet $\mathrm{A}$, tet $\mathrm{C}$, and tet $\mathrm{X}$ removal than other two hybrid CWs, while the highest removal efficiencies for tet $\mathrm{O}$ and tet $\mathrm{A}$ were found in HF-UVF and HF-DVF, respectively. The removal efficiencies for all ARGs by three hybrid CWs were in the following order: DVF-UVF $>$ HF-DVF $>$ HF-UVF.

\subsection{Removal Efficiencies of Nutrients in Hybrid CWs}

The nutrients concentrations in the influent and effluent of three hybrid CWs have been shown in Figure 3. During an operation period of 84 days, the nutrients concentrations presented high variability and the average influent concentrations of $\mathrm{TN}, \mathrm{NH}_{4}{ }^{+}-\mathrm{N}, \mathrm{NO}_{3}{ }^{-}-\mathrm{N}, \mathrm{NO}_{2}{ }^{-}-\mathrm{N}$, TP, and COD were 27.20, $5.69,7.37,1.97,13.96$, and $24.24 \mathrm{mg} / \mathrm{L}$ respectively. In effluents, $\mathrm{TN}, \mathrm{NH}_{4}{ }^{-}-\mathrm{N}, \mathrm{NO}_{3}{ }^{-}-\mathrm{N}$, and $\mathrm{NO}_{2}{ }^{-}-\mathrm{N}$ were detected at the concentration of $1.03-33.99,0.00-3.60,0.02-12.17$, and $0.01-0.56 \mathrm{mg} / \mathrm{L}$, respectively. All three hybrid CWs showed quite good removal effects on nutrients, with the average removal efficiencies of $54-76 \%$ for $\mathrm{TN}, 68-95 \%$ for $\mathrm{NH}_{4}{ }^{+}-\mathrm{N}, 59-86 \%$ for $\mathrm{NO}_{3}{ }^{-}-\mathrm{N}$, and $47-90 \%$ for $\mathrm{NO}_{2}{ }^{-}-\mathrm{N}$ (Table 1). The HF-UVF presented relatively higher average TN removal efficiency compared with other 
two CWs $(p>0.05)$, while DVF-UVF had the highest average removal efficiencies of $\mathrm{NH}_{4}{ }^{+}-\mathrm{N}^{-} \mathrm{NO}_{3}{ }^{-}-\mathrm{N}$, and $\mathrm{NO}_{2}^{-}-\mathrm{N}(95 \%, 87 \%$, and $90 \%$, respectively) among three hybrid CWs.
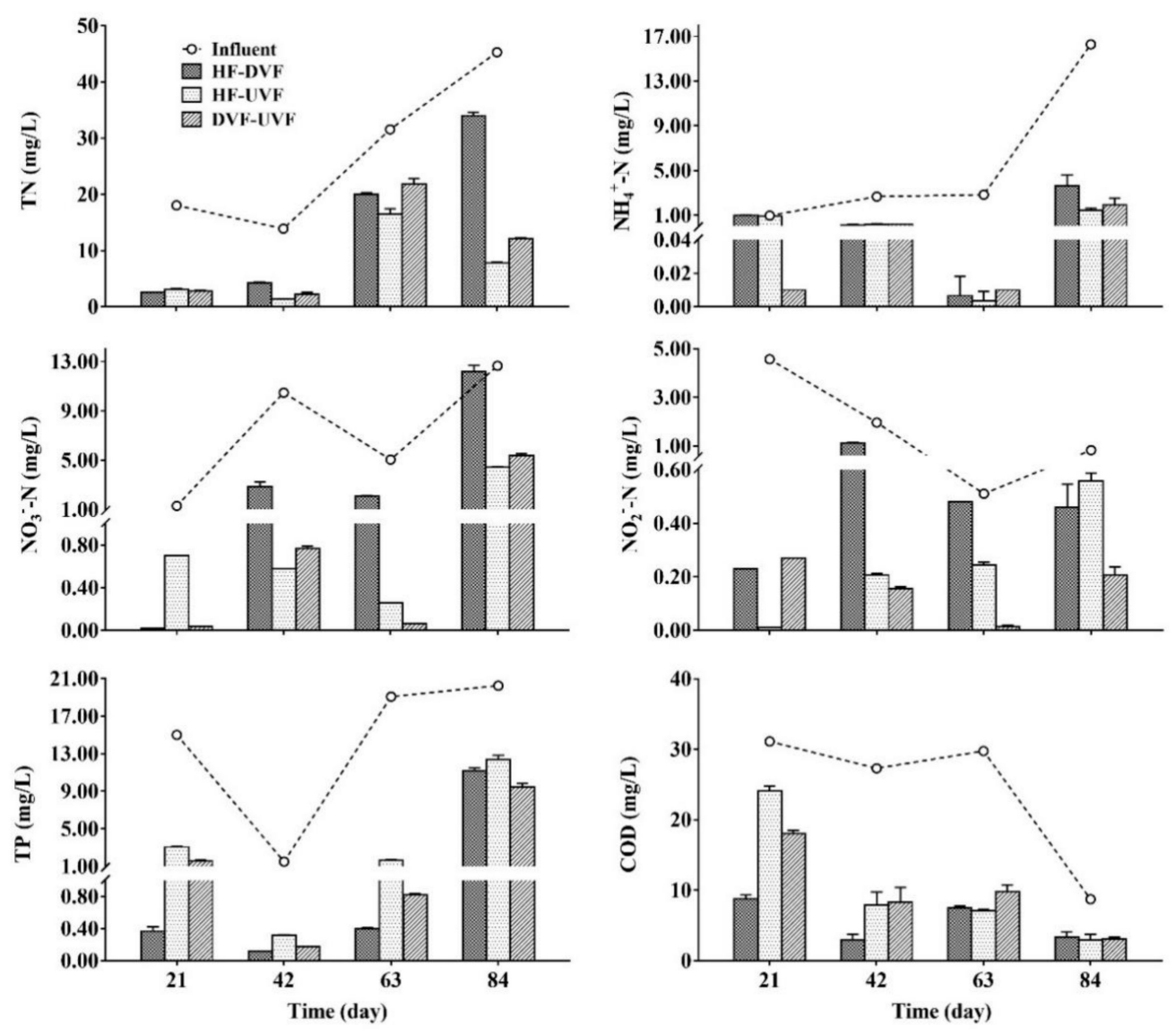

Figure 3. Nutrients concentrations in the influent and effluent of different hybrid constructed wetlands.

In three effluents, the concentrations of COD and TP ranged from 3.01 to 31.13 and 0.12 to 11.19 $\mathrm{mg} / \mathrm{L}$, respectively (Figure 3). The COD and TP removal efficiencies in HF-DVF were $74 \%$ and $83 \%$, which were both higher than those in HF-UVF (59\% for COD and 72\% for TP) and DVF-UVF (61\% for COD and $82 \%$ for TP) $(p>0.05)$ (Table 1$)$. The removal efficiencies for all nutrients by three hybrid CWs were in the following order: DVF-UVF $>$ HF-UVF $>$ HF-DVF.

\section{Discussion}

In the present study, the removal efficiencies of TMS, DOC, and total antibiotics were relatively stable and higher than $98 \%$ for all three hybrid CWs. However, previous researches showed that TMS and DOC removal efficiencies were only $51 \%$ and $71 \%$ in HF CW [23,24]. These two different results indicated that compared with single $\mathrm{CW}$, two-stage hybrid CWs present better performances in removing TMS and DOC from wastewater, even when the antibiotic concentrations are much higher than those in previous researches. The better performances of hybrid CWs were mainly attributed to long HRT, which would consequently promote the adsorption and degradation of antibiotics [3,31,32]. In three hybrid CWs, TMS removal efficiencies were slightly better than DOC, even TMS concentration was much higher in wastewater. Previous studies showed that antibiotics with higher log Kow were easily to be adsorbed by sediments and absorbed by plants [33-35]. Therefore, the high log Kow of TMS may be responsible for the relatively high removal efficiencies in the CWs. In the present study, the removal efficiencies of TMS, DOC, and total antibiotics had no significant differences among three hybrid CWs. The results indicated that the configuration of hybrid CWs had no obvious effect on antibiotics removal in wastewater, which might be due to the fact that the concentration of influent 
antibiotics was enough high to conceal the differences on effluent antibiotics levels among three hybrid CWs.

IntI1 was common genetic assembly platform and associated with the proliferation [36]. In the present study, intI1 was found to be the most abundant gene, implying that intI1 might capture the tet and erm genes and contributed to the spread of ARGs [37]. A greater abundance of tet $\mathrm{X}$ and tet $\mathrm{G}$ were also found in the influent. Compared with other ARGs, tet genes had higher transition probabilities from fecal microorganisms to environmental bacteria to achieve high abundances [38]. Moreover, the proliferation of tet $\mathrm{G}$ could also be promoted by the abundant intI1 in wastewater [27]. As we know, the abundance of 16S rRNA could reflect the bacteria level in wastewater [39]. In the present study, DVF-UVF presented lower effluent 16S rRNA abundance and higher removal efficiency compared with HF-DVF and HF-UVF, and the differences increased as time went on. Therefore, the bacteria might be arrested growth and removed in DVF-UVF, probably because of the predominant anaerobic conditions in the DVF-UVF CWs [40]. By contrast, HF and DVF had better oxygen supply than UVF, which might promote the growth of bacteria. As a result, a higher abundance of effluent 16S rRNA was found in HF-DVF during the whole experiment period.

Consistent with the observation of 16S rRNA, intI1, Eerm, and $\sum$ tet showed better removal efficiencies in DVF-UVF, which were both more than $87 \%$. However, when using single UVF, the removal efficiencies for intI1 and tet genes were only around 62\% [28]. The differences might also be attributed to the long HRT in hybrid CWs compared with single CW. Besides, the ARG abundances were positively correlated with antibiotic concentrations, therefore, the massive removal of TMS and DOC by hybrid CWs in the present study also contributed to the high removal efficiencies of ARGs [41,42]. Moreover, previous report attributed significant reduction in abundances of ARGs to the anaerobic environment in CWs [43]. Therefore, we speculated that the predominant anaerobic conditions in DVF-UVF CWs arrested bacteria growth and promoted the removal of intI1, Eerm, and $\sum$ tet consequently. For erm B, erm C, and tetW, HF-UVF and DVF-UVF showed significant higher removal efficiencies than HF-DVF. Those results also confirmed that the UVF had low oxygen supply and formed anaerobic conditions to promote the removal of the ARGs [3]. As mentioned above, we consider that compared with other two hybrid CWs, DVF-UVF performed better in ARG removal from goose wastewater.

Previous studies indicated that HF-DVF could form aerobic-anaerobic condition and combine aerobic with anaerobic microbial degradation to benefit TP removal [20,44]. In this study, HF-DVF showed relatively higher TP and COD removal efficiencies compared with the other two hybrid CWs. The major reason might be that HF-DVF improved the degradation activity and proliferation of microbes, which was consistent with high 16S rRNA abundance in HF-DVF [45]. On the contrary, DVF-UVF had the highest removal efficiencies of $\mathrm{NH}_{4}{ }^{-}-\mathrm{N}, \mathrm{NO}_{3}{ }^{-}-\mathrm{N}$, and $\mathrm{NO}_{2}{ }^{-}-\mathrm{N}$ among three hybrid CWs, which were $95 \%, 86 \%$, and $80 \%$ respectively. Due to the predominant anoxic-anaerobic conditions, DVF-UVF could promote the establish of anaerobic ammonium oxidation (anammox), which was an effective $\mathrm{NH}_{4}{ }^{+}-\mathrm{N}$ and $\mathrm{NO}_{2}{ }^{-}-\mathrm{N}$ removal pathway $[40,46]$. Previous research also verified that the major $\mathrm{N}$ was removed by anammox process in DVF-UVF CWs [47]. Therefore, we believe that anammox might be established in DVF-UVF and contributed to the removal of $\mathrm{NH}_{4}{ }^{+}-\mathrm{N}, \mathrm{NO}_{3}-\mathrm{N}$, and $\mathrm{NO}_{2}{ }^{-}-\mathrm{N}$. Besides, the results also indicate that organic $\mathrm{N}$ might not be effectively removed by DVF-UVF because of TN removal efficiencies was relatively low and it might also contribute to the high COD in DVF-UVF.

\section{Conclusions}

Our results clarified the effect of two-stage combinations of CWs on removal of high-concentration antibiotics, ARGs, and nutrients from goose wastewater. The main conclusions are listed as below:

(1) All three hybrid CWs were efficient for removing high-concentration TMS and DOC from wastewater and the combined configuration of hybrid CWs has no significant effect on the removal of antibiotics; 
(2) DVF-UVF CWs possessed better ARG removal efficiencies from wastewater, probably due to the inhibition of bacterial growth;

(3) DVF-UVF CWs might promote the establish of anammox and benefit for removing $\mathrm{N}$ from wastewater;

(4) DVF-UVF CWs was the optimal choice for removing pollutants from goose wastewater.

Supplementary Materials: The following are available online at http://www.mdpi.com/1660-4601/16/20/4030/s1, Table S1: Synthetic of oligonucleotides used in this study.

Author Contributions: Conceptualization, C.W.; Data curation, C.Z. and H.Z.; Formal analysis, Y.L. and C.W.; Investigation, Z.L.; Methodology, X.H. and Z.Z.; Project administration, X.H., Y.L., Z.L., J.X., and Z.Z.; Software, H.Z.; Validation, Q.W.; Writing—original draft, X.H.; Writing—review and editing, X.H.

Funding: This study was supported by the Earmarked Fund for Chongqing Basic Science and Frontier Technology Research (cstc2017jcyjAX0336), the Earmarked Fund for China Agriculture Research System (CARS-42-22), the Earmarked Fund for Chongqing Social Welfare and Livelihood Security (cstc2017shms-xdny80047), the Chongqing Agricultural Development Foundation (17405).

Conflicts of Interest: The authors declare no conflict of interest.

\section{References}

1. Pan, M.; Chu, L. Occurrence of antibiotics and antibiotic resistance genes in soils from wastewater irrigation areas in the Pearl River Delta region, southern China. Sci. Total Environ. 2018, 624, 145-152. [CrossRef] [PubMed]

2. Sarmah, A.K.; Meyer, M.T.; Boxall, A.B. A global perspective on the use, sales, exposure pathways, occurrence, fate and effects of veterinary antibiotics (VAs) in the environment. Chemosphere 2006, 65, 725-759. [CrossRef] [PubMed]

3. Huang, X.; Zheng, J.; Liu, C.; Liu, L.; Liu, Y.; Fan, H. Removal of antibiotics and resistance genes from swine wastewater using vertical flow constructed wetlands: Effect of hydraulic flow direction and substrate type. Chem. Eng. J. 2017, 308, 692-699. [CrossRef]

4. Van Boeckel, T.P.; Brower, C.; Gilbert, M.; Grenfell, B.T.; Levin, S.A.; Robinson, T.P.; Teillant, A.; Laxminarayan, R. Global trends in antimicrobial use in food animals. Proc. Nat. Acad. Sci USA 2015, 112, 5649-5654. [CrossRef]

5. Manyi-Loh, C.; Mamphweli, S.; Meyer, E.; Okoh, A. Antibiotic use in agriculture and its consequential resistance in environmental sources: Potential public health implications. Molecules 2018, 23, 795. [CrossRef]

6. Chen, J.; Wei, X.-D.; Liu, Y.-S.; Ying, G.-G.; Liu, S.-S.; He, L.-Y.; Su, H.-C.; Hu, L.-X.; Chen, F.-R.; Yang, Y.-Q. Removal of antibiotics and antibiotic resistance genes from domestic sewage by constructed wetlands: Optimization of wetland substrates and hydraulic loading. Sci. Total Environ. 2016, 565, 240-248. [CrossRef]

7. Qiao, M.; Ying, G.-G.; Singer, A.C.; Zhu, Y.-G. Review of antibiotic resistance in China and its environment. Environ. Int. 2018, 110, 160-172. [CrossRef]

8. Wei, R.; He, T.; Zhang, S.; Zhu, L.; Shang, B.; Li, Z.; Wang, R. Occurrence of seventeen veterinary antibiotics and resistant bacterias in manure-fertilized vegetable farm soil in four provinces of China. Chemosphere 2019, 215, 234-240. [CrossRef]

9. Cui, C.; Han, Q.; Jiang, L.; Ma, L.; Jin, L.; Zhang, D.; Lin, K.; Zhang, T. Occurrence, distribution, and seasonal variation of antibiotics in an artificial water source reservoir in the Yangtze River delta, East China. Environ. Sci. Pollut. Res. 2018, 25, 19393-19402. [CrossRef]

10. Liu, X.; Zhang, H.; Li, L.; Fu, C.; Tu, C.; Huang, Y.; Wu, L.; Tang, J.; Luo, Y.; Christie, P. Levels, distributions and sources of veterinary antibiotics in the sediments of the Bohai Sea in China and surrounding estuaries. Mar. Pollut. Bull. 2016, 109, 597-602. [CrossRef]

11. Chen, C.; Zheng, L.; Zhou, J.; Zhao, H. Persistence and risk of antibiotic residues and antibiotic resistance genes in major mariculture sites in Southeast China. Sci. Total Environ. 2017, 580, 1175-1184. [CrossRef]

12. Stange, C.; Yin, D.; Xu, T.; Guo, X.; Schäfer, C.; Tiehm, A. Distribution of clinically relevant antibiotic resistance genes in Lake Tai, China. Sci. Total Environ. 2019, 655, 337-346. [CrossRef] [PubMed] 
13. Chen, J.; Deng, W.-J.; Liu, Y.-S.; Hu, L.-X.; He, L.-Y.; Zhao, J.-L.; Wang, T.-T.; Ying, G.-G. Fate and removal of antibiotics and antibiotic resistance genes in hybrid constructed wetlands. Environ. Pollut. 2019, 249, 894-903. [CrossRef]

14. Vymazal, J. Plants used in constructed wetlands with horizontal subsurface flow: A review. Hydrobiologia 2011, 674, 133-156. [CrossRef]

15. Ibekwe, A.M.; Murinda, S.E. Continuous flow-constructed wetlands for the treatment of swine waste water. Int. J. Environ. Res. Public Health 2018, 15, 1369. [CrossRef]

16. Vymazal, J. The use of hybrid constructed wetlands for wastewater treatment with special attention to nitrogen removal: A review of a recent development. Water Res. 2013, 47, 4795-4811. [CrossRef]

17. Wang, M.; Zhang, D.Q.; Dong, J.W.; Tan, S.K. Constructed wetlands for wastewater treatment in cold climate-A review. J. Environ. Sci. 2017, 57, 293-311. [CrossRef]

18. Vymazal, J.; Kröpfelová, L. Multistage hybrid constructed wetland for enhanced removal of nitrogen. Ecol. Eng. 2015, 84, 202-208. [CrossRef]

19. Li, Y.; Zhu, G.; Ng, W.J.; Tan, S.K. A review on removing pharmaceutical contaminants from wastewater by constructed wetlands: Design, performance and mechanism. Sci. Total Environ. 2014, 468, 908-932. [CrossRef]

20. Liu, H.; Hu, Z.; Zhang, J.; Ngo, H.H.; Guo, W.; Liang, S.; Fan, J.; Lu, S.; Wu, H. Optimizations on supply and distribution of dissolved oxygen in constructed wetlands: A review. Bioresour. Technol. 2016, 214, 797-805. [CrossRef] [PubMed]

21. Liu, L.; Liu, Y.-H.; Wang, Z.; Liu, C.-X.; Huang, X.; Zhu, G.-F. Behavior of tetracycline and sulfamethazine with corresponding resistance genes from swine wastewater in pilot-scale constructed wetlands. J. Hazard. Mater. 2014, 278, 304-310. [CrossRef] [PubMed]

22. Glisson, J.R. Bacterial respiratory diseases of poultry. Poult. Sci. 1998, 77, 1139-1142. [CrossRef] [PubMed]

23. Hijosa-Valsero, M.; Fink, G.; Schlüsener, M.P.; Sidrach-Cardona, R.; Martín-Villacorta, J.; Ternes, T.; Bécares, E. Removal of antibiotics from urban wastewater by constructed wetland optimization. Chemosphere 2011, 83, 713-719. [CrossRef] [PubMed]

24. Verlicchi, P.; Galletti, A.; Petrovic, M.; Barceló, D.; Al Aukidy, M.; Zambello, E. Removal of selected pharmaceuticals from domestic wastewater in an activated sludge system followed by a horizontal subsurface flow bed-analysis of their respective contributions. Sci. Total Environ. 2013, 454, 411-425. [CrossRef] [PubMed]

25. Hou, S. Present situation, future development trend and suggestions of waterfowl industry in 2018. Chin. J. Anim. Husb. 2019, 55, 124-128.

26. Chen, J.; Michel, F.C.; Sreevatsan, S.; Morrison, M.; Yu, Z. Occurrence and persistence of erythromycin resistance genes ( $\mathrm{erm})$ and tetracycline resistance genes (tet) in waste treatment systems on swine farms. Microb. Ecol. 2010, 60, 479-486. [CrossRef]

27. Cheng, W.; Chen, H.; Su, C.; Yan, S. Abundance and persistence of antibiotic resistance genes in livestock farms: A comprehensive investigation in eastern China. Environ. Int. 2013, 61, 1-7. [CrossRef]

28. Huang, X.; Liu, C.; Li, K.; Su, J.; Zhu, G.; Liu, L. Performance of vertical up-flow constructed wetlands on swine wastewater containing tetracyclines and tet genes. Water Res. 2015, 70, 109-117. [CrossRef]

29. Sui, Q.; Zhang, J.; Tong, J.; Chen, M.; Wei, Y. Seasonal variation and removal efficiency of antibiotic resistance genes during wastewater treatment of swine farms. Environ. Sci. Pollut. Res. 2017, 24, 9048-9057. [CrossRef]

30. Federation, W.E.; Association, A.P.H. Standard Methods for the Examination of Water and Wastewater; American Public Health Association (APHA): Washington, DC, USA, 2005.

31. Conkle, J.L.; White, J.R.; Metcalfe, C.D. Reduction of pharmaceutically active compounds by a lagoon wetland wastewater treatment system in Southeast Louisiana. Chemosphere 2008, 73, 1741-1748. [CrossRef]

32. Dan, A.; Yang, Y.; Dai, Y.-N.; Chen, C.-X.; Wang, S.-Y.; Tao, R. Removal and factors influencing removal of sulfonamides and trimethoprim from domestic sewage in constructed wetlands. Bioresour. Technol. 2013, 146, 363-370. [CrossRef] [PubMed]

33. Carvalho, P.N.; Pirra, A.; Basto, M.C.P.; Almeida, C.M.R. Activated sludge systems removal efficiency of veterinary pharmaceuticals from slaughterhouse wastewater. Environ. Sci. Pollut. Res. 2013, 20, 8790-8800. [CrossRef] [PubMed] 
34. Leston, S.; Freitas, A.; Rosa, J.; Barbosa, J.; Lemos, M.F.; Pardal, M.Â.; Ramos, F. A multiresidue approach for the simultaneous quantification of antibiotics in macroalgae by ultra-high performance liquid chromatography-tandem mass spectrometry. J. Chromatogr. B 2016, 1033, 361-367. [CrossRef] [PubMed]

35. Sharma, V.K.; Johnson, N.; Cizmas, L.; McDonald, T.J.; Kim, H. A review of the influence of treatment strategies on antibiotic resistant bacteria and antibiotic resistance genes. Chemosphere 2016, 150, 702-714. [CrossRef]

36. Mazel, D. Integrons: Agents of bacterial evolution. Nat. Rev. Microbiol. 2006, 4, 608. [CrossRef]

37. Xu, Y.; Guo, C.; Luo, Y.; Lv, J.; Zhang, Y.; Lin, H.; Wang, L.; Xu, J. Occurrence and distribution of antibiotics, antibiotic resistance genes in the urban rivers in Beijing, China. Environ. Pollut. 2016, 213, 833-840. [CrossRef]

38. Liu, L.; Liu, C.; Zheng, J.; Huang, X.; Wang, Z.; Liu, Y.; Zhu, G. Elimination of veterinary antibiotics and antibiotic resistance genes from swine wastewater in the vertical flow constructed wetlands. Chemosphere 2013, 91, 1088-1093. [CrossRef]

39. Dunbar, J.; Takala, S.; Barns, S.M.; Davis, J.A.; Kuske, C.R. Levels of bacterial community diversity in four arid soils compared by cultivation and 16S rRNA gene cloning. Appl. Environ. Microbiol. 1999, 65, 1662-1669.

40. Tao, M.; He, F.; Xu, D.; Li, M.; Wu, Z. How Artificial Aeration Improved Sewage Treatment of an Integrated Vertical-Flow Constructed Wetland. Pol. J. Environ. Stud. 2010, 19, 183-191.

41. Wu, N.; Qiao, M.; Zhang, B.; Cheng, W.-D.; Zhu, Y.-G. Abundance and diversity of tetracycline resistance genes in soils adjacent to representative swine feedlots in China. Environ. Sci. Technol. 2010, 44, 6933-6939. [CrossRef]

42. Berglund, B.; Khan, G.A.; Weisner, S.E.; Ehde, P.M.; Fick, J.; Lindgren, P.-E. Efficient removal of antibiotics in surface-flow constructed wetlands, with no observed impact on antibiotic resistance genes. Sci. Total Environ. 2014, 476, 29-37. [CrossRef] [PubMed]

43. McKinney, C.W.; Loftin, K.A.; Meyer, M.T.; Davis, J.G.; Pruden, A. Tet and sul antibiotic resistance genes in livestock lagoons of various operation type, configuration, and antibiotic occurrence. Environ. Sci. Technol. 2010, 44, 6102-6109. [CrossRef] [PubMed]

44. Ávila, C.; Bayona, J.M.; Martín, I.; Salas, J.J.; García, J. Emerging organic contaminant removal in a full-scale hybrid constructed wetland system for wastewater treatment and reuse. Ecol. Eng. 2015, 80, 108-116. [CrossRef]

45. Jia, W.; Zhang, J.; Li, P.; Xie, H.; Wu, J.; Wang, J. Nitrous oxide emissions from surface flow and subsurface flow constructed wetland microcosms: Effect of feeding strategies. Ecol. Eng. 2011, 37, 1815-1821. [CrossRef]

46. Wang, L.; Li, T. Anaerobic ammonium oxidation in constructed wetlands with bio-contact oxidation as pretreatment. Ecol. Eng. 2011, 37, 1225-1230. [CrossRef]

47. Hu, Y.; He, F.; Ma, L.; Zhang, Y.; Wu, Z. Microbial nitrogen removal pathways in integrated vertical-flow constructed wetland systems. Bioresour. Technol. 2016, 207, 339-345. [CrossRef] 